\title{
Effects of Ginger (Zingiber officinale) Rhizomes Essential Oil on Some Reproductive Parameters in Laying Japanese Quail (Coturnix coturnix japonica)
}

\author{
Herve Tchoffo, Ferdinand Ngoula*, Jean Raphael Kana, Augustave Kenfack, \\ Victor Herman Ngoumtsop, Narcisse Bertin Vemo \\ Department of Animfal Science, Faculty of Agronomy and Agricultural Sciences, University of Dschang, Dschang, Cameroon \\ Email: ^ferdinand.ngoula@univ-dschang.org
}

How to cite this paper: Tchoffo, H., Ngoula, F., Kana, J.R., Kenfack, A., Ngoumtsop, V.H. and Vemo, N.B. (2017) Effects of Ginger (Zingiber officinale) Rhizomes Essential Oil on Some Reproductive Parameters in Laying Japanese Quail (Coturnix coturnix japonica). Advances in Reproductive Sciences, 5, 64-74.

https://doi.org/10.4236/arsci.2017.54008

Received: September 18, 2017

Accepted: November 24, 2017

Published: November 27, 2017

Copyright $\odot 2017$ by authors and Scientific Research Publishing Inc. This work is licensed under the Creative Commons Attribution International License (CC BY 4.0).

http://creativecommons.org/licenses/by/4.0/

\begin{abstract}
To assess the effect of ginger rhizomes essential oil on some reproductive parameters of laying birds, 80 female Japanese quails (Coturnix coturnix japonica) aged 3 weeks and weighing between 120 - $130 \mathrm{~g}$ were randomly assigned into 4 dietary treatment groups in a completely randomized design. From 3 till 13 weeks, birds in group 1 (control) received distilled water orally $(100 \mu \mathrm{l} / \mathrm{kg}$ body weight), while the other three test groups during the same period, received respectively by gavage 50,100 and $150 \mu \mathrm{l}$ of ginger roots essential oil per kg body weight. At 11 weeks old, eight birds per group in each treatment were randomly selected and slaughtered, blood samples collected for analysis. On the other hand, the remaining females were maintained 3 with one untreated male in identical boxes per treatment, for fertility assessment, eggs characteristics and hatchability traits. Throughout the experiment, biochemical parameters, eggs characteristics, fertility and hatchability traits were analyzed. No significant change ( $\mathrm{p}>$ 0.05 ) was observed during the experimental period for body and relative ovary weights. Contrary, the relative uterus weight significantly increased $(\mathrm{p}<0.05)$ in dose-dependent manner. The level of serum total proteins, LH, FSH and estradiol significantly increased $(\mathrm{p}<0.05)$ in a dose-dependent manner. Also, fertility, hatchability of fertile eggs, total hatchability and chick's weight significantly increased $(\mathrm{p}<0.05)$ in birds received 100 and $150 \mu \mathrm{l} / \mathrm{kg}$ b.w compared to those of control group. On the other hand, embryonic mortality decreased significantly ( $\mathrm{p}<0.05$ ) whatever the ginger rhizomes essential oil dose. It was concluded that ginger rhizomes essential oil enhances bird reproductive performances, proteins and reproductive hormone levels and hatchability traits in treated female quails.
\end{abstract}




\section{Keywords}

Eggs Characteristics, Females Japanese Quail, Ginger Rhizomes Essential Oil, Hatchability Traits

\section{Introduction}

Essential oils are odorous organic substances found naturally in various parts of aromatic plants [1]. They are volatile and highly concentrated in active molecules having diverse properties including antiparasitic, antifungal, antibacterial, anti-inflammatory and antioxidant activities [1] [2]. In animal production, these properties are utilized to limit the loss of energy in favor of growth and reproduction.

Ginger, the rhizome of Zingiber officinale, is one of the spices widely used worldwide for various foods and as an herbal medicine [3]. Studies on ginger extracts and essential oil show that, they contain flavonoids, phenolic compounds (gingerdiol, gingerol, gingerdione and shogaols) [4] [5] [6], Fe, $\mathrm{Mg}, \mathrm{Ca}$ and vitamin C [7], having antibacterial, immunomodulatory, anti-inflammatory and androgenic effects. Ginger is a strong anti-oxidant substance and may either mitigate or prevent generation of free radicals [8] [9] [10]. Positive effects of ginger on blood circulation and cholesterol, gastric secretion and enterokinesia were reported by Ali et al. [10]. In addition, ginger has been found to enhance bird growth performance, blood biochemistry, egg production and quality [11].

All of these have favorable effects on animal productivity, which may have partially contributed to increase reproductive performances of laying quail in this study. Abdollah et al. [12] indicated that supplementation of laying hen diet with ginger root at the rate of $0.5 \%$ or $0.75 \%$ increased egg production. In addition, Malekizadeh et al. [13] reported that ginger root powder at the level of $1 \%$ in laying hens diet reduced total cholesterol level and increased egg production compared to the control diet. These studies showed some positive effects of ginger root powder on reproductive performances but, the effects of ginger rhizomes essential oil which is highly concentrated in active molecules [14], show limited studies on animal reproduction, especially in birds. The objective of this study is to investigate the possible effects of ginger rhizomes essential oil on some reproductive parameters in laying Japanese quails.

\section{Materials and Methods}

\subsection{Study Area}

The study was carried out at Teaching and Research Farm of the University of Dschang ( $\mathrm{LN} 05^{\circ} 26^{\prime}, \mathrm{LE} 10^{\circ} 3^{\prime}$ ). Dschang is located about $1420 \mathrm{~m}$ above sea level. Climate is Sudano guinean temperated by altitude and about $2000 \mathrm{~mm}$ of rainfall spread over a single season from mid-March to mid-November. The average temperature is $20^{\circ} \mathrm{C}$ and relative humidity generally exceeds $60 \%$. 


\subsection{Plant Material and Essential Oil Extraction}

Fresh Ginger roots were harvested from the agricultural zone of Santchou (LN $5^{\circ} 16^{\prime} 55^{\prime \prime}$, LE $\left.9^{\circ} 58^{\prime} 27^{\prime \prime}\right)$ in the Menoua division, West Region of Cameroon, washed and then ground in a mortar in order to liberate the tissues. Oil extraction was done by hydrodistillation in PYTORICA Laboratory, Banapriso, Douala Cameroon following the protocol described by Wang and Weller [15].

\subsection{Animal Material}

Ninety-six female Japanese quails (3 weeks old, weight: 120 - $130 \mathrm{~g}$ ) coming from the Teaching and Research Farm of the University of Dschang were used for the experiment. Each bird was identified by a ring bearing his number in one of its paws.

\subsection{Experimental Design}

At the beginning of the experiment, birds were weighed and then assigned randomly into 4 dietary treatment groups in completely randomized design. From 3 till 13 weeks, quails in group 1 (control) received orally distilled water $(100 \mu \mathrm{l} / \mathrm{kg}$ body weight), while birds of the other three test groups during the same period, received respectively by gavage 50,100 and $150 \mu \mathrm{l}$ per kg body weight of Ginger roots essential oil. At 12 weeks old, eight female quails per treatment were randomly selected and fasted for 24 hours, weighed and slaughtered as indicated by Jourdain [16], blood samples were collected to analysis. On the other hand, the remaining females per treatment were maintained 3 with one untreated male in identical boxes under the same environmental conditions, for fertility assessment, egg characteristics and hatchability traits. Feed (Table 1) and fresh water were given ad libitum in adapted equipment.

\section{Data Collection}

\subsection{Blood and Egg Sampling Preparation}

At the slaughter moment, Blood samples were collected from the jugular vein in non-heparinized tubes and then centrifuged at $3000 \mathrm{rpm}$ for $15 \mathrm{~min}$. The resultant serum (supernatant) was stored in $1.5 \mathrm{ml}$ Eppendorf tubes at $-20^{\circ} \mathrm{C}$ for biochemical analysis. In addition, 12 eggs (3/unit) were randomly picked out from each treatment on the same day of blood sampling. The yolk of each egg was manually isolated and homogenized with ice-cold isotonic physiological saline $(0.154 \mathrm{~mol} / \mathrm{L} ; \mathrm{pH}=7.4)$ in the ratio of $1: 9$ for $5 \mathrm{~min}$. The homogenate was then centrifuged at $3000 \mathrm{rpm}$ for $30 \mathrm{~min}$. The resultant supernatants were subsequently stored at $-20^{\circ} \mathrm{C}$ for cholesterol analysis.

\subsection{Organ Weight}

After killing birds, organs including ovary and uterus were carefully removed, rid of adipose tissue, blotted dry and weighed separately. The relative organ weight was calculated using the above formula: 
Table 1. Centesimal composition and bromatological characteristics of the experimental feed.

\begin{tabular}{cc}
\hline Constituents & Amount $(\mathrm{kg} / 100 \mathrm{~kg})$ \\
\hline Corn & 60 \\
Bran wheat & 4.5 \\
Soybean meal & 22 \\
Fishmeal & 4.5 \\
Oyster shell & 2 \\
Bone meal & 2 \\
Premix 5\%* & 5 \\
Total & 100 \\
Bromatological characteristics & \\
Crude protein (\%) & 20.15 \\
Metabolizable energy (Kcal/Kg) & 2906.80 \\
Calcium (\%) & 2.03 \\
Phosphorus (\%) & 1.27 \\
Lysine (\%) & 0.44 \\
Methionine (\%) & 0.14 \\
Sodium (\%) & 0.22 \\
\hline
\end{tabular}

${ }^{*}$ Premix 5\%: mixture of vitamins A, B complex, D, K and E principally and incorporated at 5\% in diet.

$$
\text { Relative organ weight }(\%)=\frac{\text { Organ weight }(\mathrm{mg})}{\text { Live body weight }(\mathrm{g})} \times 100
$$

\subsection{Biochemical Analysis}

Serum biochemical parameters including total protein contents and cholesterol were determined using Biuret methods [17] and colorimetric methods described in commercial kit (CHRONOLAB, Ref: 101-0576) respectively. The total globulins were calculated as recommended by Abdel-Fattah et al. [18]. Serum LH, FSH and estradiol were determined using a commercial kit (ELISA) (Diagnosis Automation, Inc., Calabasas, USA). The egg yolk cholesterol was determined using the same method as for serum samples.

\subsection{Fertility, Hatchability Traits and Chick Weight}

A total of 56 eggs per group were collected during 8 days, weighted individually and incubated. After artificial incubation for 19 days, all un-hatched eggs were cracked and classified as infertile or presenting an embryonic mortality. The fertility rate was then calculated by dividing the number of fertile eggs with the total number of eggs incubated.

For chick's weigh, chicks per group were collected at the hatching period and individually weighted. The chick's weigh was then calculated by dividing the to- 
tal chick's weight with the total number of chicks.

\subsection{Statistical Analysis}

Data collected were subjected to one-way analysis of variance (ANOVA) at p < 0.05 . When differences were significant, Duncan multiple range test was used to separate means. All statistical analyses were performed using SPSS 20.0.

\section{Results}

\subsection{Effects of Ginger Roots Essential Oil on Body and Reproductive Organs Weight in Female Japanese Quails}

The effects of ginger rhizomes essential oil on the body weight and the relative reproductive organ weights are shown in Table 1 . Ginger roots essential oil had no significant effect $(\mathrm{p}<0.05)$ on final body weight, body weight gain and on relative ovary weight. Furthermore, the relative uterus weight increases significantly $(\mathrm{p}<0.05)$ in female quail treated with 100 and $150 \mu \mathrm{l} / \mathrm{kg}$ b.w compared to birds of control group and to those received $50 \mu \mathrm{l} / \mathrm{kg}$ b.w.

\subsection{Effects of Ginger Roots Essential Oil on Biochemical Parameters in Female Japanese Quails}

The effects of ginger rhizomes essential oil on biochemical parameters as shown in Table 2 reveal that, the level of serum total proteins increased significantly ( $\mathrm{p}$ $<0.05)$ in quails which received different doses of ginger rhizomes essential oil compared to control birds. No significant difference for this parameter was recorded when only birds receiving ginger rhizome essential oil were compared. The level of globulins increased in female Japanese quails treated with ginger rhizome essential oil compared to controls but no significant difference was recorded. On the other hand, oral administration of 100 and $150 \mu \mathrm{l} / \mathrm{kg}$ b.w of ginger rhizomes essential oil for 13 weeks in Japanese quail significantly $(p<0.05)$ increase LH, FSH and estradiol concentrations compared to those of control group.

Table 2. Effects of ginger rhizomes essential oil on the final body weight, body weight gain and the relative weight of the reproductive organs in Japanese quail.

\begin{tabular}{|c|c|c|c|c|c|}
\hline \multirow{2}{*}{ Parameters } & \multirow{2}{*}{$\begin{array}{l}\text { Control } \\
(n=12)\end{array}$} & \multicolumn{3}{|c|}{ Essential oil doses ( $\mu \mathrm{l} / \mathrm{kg}$ body weight) } & \multirow{2}{*}{$\mathrm{p}$ value } \\
\hline & & $50(\mathrm{n}=8)$ & $100(\mathrm{n}=8)$ & $150(\mathrm{n}=8)$ & \\
\hline Final body weight (g) & $231.25 \pm 16.52^{\mathrm{a}}$ & $226.71 \pm 15.11^{\mathrm{a}}$ & $230.75 \pm 36.96^{\mathrm{a}}$ & $229.65 \pm 21.79^{\mathrm{a}}$ & 0.98 \\
\hline Body weight gain (g) & $258.29 \pm 37.54^{\mathrm{a}}$ & $251.86 \pm 33.34^{\mathrm{a}}$ & $250.86 \pm 39.52^{\mathrm{a}}$ & $255.14 \pm 42.18^{\mathrm{a}}$ & 1.00 \\
\hline \multicolumn{6}{|l|}{$\begin{array}{l}\text { Organ weights } \\
(\mathrm{g} / 100 \mathrm{~g} \mathrm{bw})\end{array}$} \\
\hline Ovary & $0.06 \pm 0.01^{\mathrm{a}}$ & $0.07 \pm 0.03^{\mathrm{a}}$ & $0.07 \pm 0.02^{\mathrm{a}}$ & $0.07 \pm 0.02^{\mathrm{a}}$ & 0.69 \\
\hline Uterus & $1.14 \pm 0.11^{\mathrm{b}}$ & $1.44 \pm 0.19^{\mathrm{b}}$ & $2.44 \pm 0.43^{\mathrm{a}}$ & $2.15 \pm 0.31^{\mathrm{a}}$ & 0.00 \\
\hline
\end{tabular}

$(a, b, c)$ On the same line, values affected by the same letter were not significantly different $(\mathrm{p}>0.05) . \mathrm{n}=$ number of Coturnix coturnix japonica; $\mathrm{p}=$ probability; Values are presented as Means \pm standard deviation. 


\subsection{Effects of Ginger Rhizomes Essential Oil on Egg Characteristics, Hatchability Traits and Chick Weight in Female Japanese Quails}

\subsubsection{Egg Characteristics}

Data in Table 3 showed that, egg weight increased significantly $(\mathrm{p}<0.05)$ in Japanese quail received ginger rhizomes essential oil at all doses compared to control one. In addition, the value of this parameter in group of birds treated with 100 $\mu \mathrm{l} / \mathrm{kg}$ b.w was significantly higher $(\mathrm{p}<0.05)$ compared to those of others treated groups. On the other hand, oral administration of ginger rhizomes essential oil had no significant effects $(\mathrm{p}<0.05)$ on egg shape index.

\subsubsection{Hatchability Traits}

As presented in Table 4, fertility, hatchability of fertile eggs and total hatchability rates increased significantly $(\mathrm{p}<0.05)$ in Japanese quails treated with 100 and $150 \mu \mathrm{l} / \mathrm{kg}$ b.w of ginger roots essential compared to those of control group and to those which received $50 \mu \mathrm{l} / \mathrm{kg}$ b.w. Furthermore, embryonic mortality rate decreased significantly $(\mathrm{p}<0.05)$ in treated quail compared to controls. When compare only the treated groups, birds which received $100 \mu \mathrm{l} / \mathrm{kg}$ b.w presented the lowest embryonic mortality rate compared to those treated with 50 and $150 \mu \mathrm{l} / \mathrm{kg}$ b.w of ginger rhizomes essential oil.

\subsubsection{Chick's Weight}

Chick's weight significantly increased in female quails which received 100 and 150 $\mu \mathrm{l} / \mathrm{kg}$ b.w of ginger rhizomes essential oil compared to control birds (Table 4). When compare only the treated groups, chicks' weight was comparable whatever the ginger rhizomes essential oil dose.

\section{Discussion}

Because of its diverse properties, ginger rhizomes essential oil was administered orally to female Japanese quail in order to ameliorate its reproductive performances. Results of this study suggested that oral administration of ginger rhizomes essential oil had no significant effect $(p>0.05)$ in final body weight. This

Table 3. Effects of ginger rhizomes essential oil on biochemical parameters in Japanese quail.

\begin{tabular}{cccccc}
\hline \multirow{2}{*}{$\begin{array}{c}\text { Serum biochemical } \\
\text { characteristics }\end{array}$} & $\begin{array}{c}\text { Control } \\
(\mathrm{n}=8)\end{array}$ & \multicolumn{2}{c}{ Essential oil doses $(\mu \mathrm{l} / \mathrm{kg}$ body weight $)$} & p value \\
\cline { 3 - 5 } & $\mathbf{5 0}(\mathrm{n}=\mathbf{8})$ & $\mathbf{1 0 0}(\mathrm{n}=\mathbf{8})$ & $\mathbf{1 5 0}(\mathrm{n}=\mathbf{8})$ & & \\
\hline Total proteins $(\mathrm{g} / \mathrm{dl})$ & $3.28 \pm 0.19^{\mathrm{b}}$ & $3.76 \pm 0.35^{\mathrm{a}}$ & $3.89 \pm 0.09^{\mathrm{a}}$ & $3.68 \pm 0.48^{\mathrm{a}}$ & 0.01 \\
Total globulins $(\mathrm{g} / \mathrm{dl})$ & $1.07 \pm 0.08^{\mathrm{a}}$ & $1.29 \pm 0.22^{\mathrm{a}}$ & $1.18 \pm 0.07^{\mathrm{a}}$ & $1.19 \pm 0.16^{\mathrm{a}}$ & 0.26 \\
LH (mIU/ml) & $3.50 \pm 0.55^{\mathrm{c}}$ & $3.93 \pm 0.45^{\mathrm{bc}}$ & $4.10 \pm 0.36^{\mathrm{ab}}$ & $4.58 \pm 0.38^{\mathrm{a}}$ & 0.00 \\
FSH (mIU/ml) & $18.86 \pm 2.12^{\mathrm{b}}$ & $19.43 \pm 1.27^{\mathrm{b}}$ & $28.00 \pm 1.73^{\mathrm{a}}$ & $27.14 \pm 1.21^{\mathrm{a}}$ & 0.00 \\
Oestradiol $(\mathrm{ng} / \mathrm{ml})$ & $61.17 \pm 12.67^{\mathrm{c}}$ & $74.50 \pm 14.61^{\mathrm{bc}}$ & $80.17 \pm 17.89^{\mathrm{b}}$ & $96.33 \pm 4.13^{\mathrm{a}}$ & 0.00 \\
\hline
\end{tabular}

$(\mathrm{a}, \mathrm{b}, \mathrm{c})$ On the same line, values affected by the same letter were not significantly different $(\mathrm{p}>0.05) . \mathrm{n}=$ number of Coturnix coturnix japonica; $\mathrm{p}=$ probability; Values are presented as Means \pm standard deviation. 
Table 4. Effects of ginger rhizomes essential oil on egg characteristics, hatchability traits and chick weight in Japanese quail.

\begin{tabular}{|c|c|c|c|c|c|}
\hline \multirow{2}{*}{ Parameters } & \multirow{2}{*}{$\begin{array}{l}\text { Control } \\
(n=12)\end{array}$} & \multicolumn{3}{|c|}{ Essential oil doses ( $\mu \mathrm{l} / \mathrm{kg}$ body weight) } & \multirow{2}{*}{$\mathrm{p}$ value } \\
\hline & & $50(n=12)$ & $100(\mathrm{n}=12)$ & $150(n=12)$ & \\
\hline \multicolumn{6}{|l|}{ Egg characteristics } \\
\hline Egg weight (g) & $12.34 \pm 0.15^{\mathrm{c}}$ & $12.73 \pm 0.51^{\mathrm{b}}$ & $13.31 \pm 0.22^{\mathrm{a}}$ & $12.76 \pm 0.21^{\mathrm{b}}$ & 0.00 \\
\hline Shape index & $0.74 \pm 0.02^{\mathrm{a}}$ & $0.77 \pm 0.04^{\mathrm{a}}$ & $0.76 \pm 0.03^{\mathrm{a}}$ & $0.78 \pm 0.03^{\mathrm{a}}$ & 0.31 \\
\hline \multicolumn{6}{|l|}{ Hatchability traits (\%) } \\
\hline Fertility & $75.00 \pm 7.95^{\mathrm{b}}$ & $82.14 \pm 2.47^{\mathrm{ab}}$ & $89.29 \pm 5.89^{\mathrm{a}}$ & $85.71 \pm 1.58^{\mathrm{a}}$ & 0.01 \\
\hline Hatchability of fertile eggs & $65.83 \pm 11.43^{\mathrm{b}}$ & $63.09 \pm 10.85^{\mathrm{b}}$ & $91.67 \pm 8.82^{\mathrm{a}}$ & $83.09 \pm 2.345^{\mathrm{a}}$ & 0.00 \\
\hline Total hatchability & $67.86 \pm 9.37^{\mathrm{b}}$ & $64.29 \pm 6.80^{\mathrm{b}}$ & $85.71 \pm 12.37^{\mathrm{a}}$ & $76.07 \pm 7.13^{\mathrm{a}}$ & 0.03 \\
\hline Embryonic mortality & $22.92 \pm 4.17^{\mathrm{a}}$ & $13.57 \pm 2.40^{\mathrm{b}}$ & $4.17 \pm 3.14^{c}$ & $7.74 \pm 8.99^{\mathrm{bc}}$ & 0.00 \\
\hline Chick's weight (g) & $8.59 \pm 0.79^{\mathrm{b}}$ & $8.94 \pm 0.97^{\mathrm{ab}}$ & $9.65 \pm 1.36^{\mathrm{a}}$ & $9.56 \pm 1.27^{\mathrm{a}}$ & 0.03 \\
\hline
\end{tabular}

$(\mathrm{a}, \mathrm{b}, \mathrm{c})$ On the same line, values affected by the same letter were not significantly different $(\mathrm{p}>0.05) . \mathrm{n}=$ number of Coturnix coturnix japonica; $\mathrm{p}=$ probability; Values are presented as Means \pm standard deviation.

result is in close agreement with the one of Bulbul et al. [19] who found that the addition of myrtle oil at the concentration of 500 and $2000 \mathrm{mg} / \mathrm{kg}$ diet has no effect on the final live body weight of female and male Japanese quails. Also, Nahed et al. [20] reported that addition of ginger rhizome essential oil on broiler diet $(100,200$ and $300 \mathrm{mg} / \mathrm{kg}$ of diet) had no positive effects on their live body weight.

Egg weight increased in dose-dependent manner with ginger rhizomes essential oil. Our findings are in agreement with the results of Arpasova [21] who observed similar results when Thymus vulgaris or Origanum vulgare oil was supplemented at the doses of 5 and $10 \mathrm{ml} / \mathrm{kg}$ of diet at 20 weeks to laying Hy-Line Brown. This effect can be attributed to the improvement of ovary activity and overall stimulation of vitality and metabolism, or to the phenolic compounds of ginger essential oil which may increase reproductive activities, leading to increase muscle mass of reproductive organs and production performance of laying hens as shown by results of our study. On the other hand, ginger rhizomes essential oil at all doses caused significant $(p<0.05)$ decrease of embryonic mortality compared to those of control group. This result can be attributed to the increasing of egg weight. According to Othman et al. [22], the embryonic mortality decreases as the egg weight increases. This situation may be explained by the fact that heavy weight eggs have sufficient nutrients and centrally placed yolk to support embryonic growth and development [23] and consequently give the heavy outliving chicks than those of the light weight eggs.

Estradiol $\left(\mathrm{E}_{2}\right)$ is the main reproductive hormone playing a central role in the determination of egg mass and quality. It stimulates the avian liver to produce the yolk precursors vitellogenin and very-low density lipoprotein (VLDL), the primary sources of yolk protein and lipid, respectively [24]. The synthesis and secretion of 
egg albumen by the oviduct is also, in part, under estrogenic control [25]. The present study showed a significant increase in estradiol with the increase of ginger rhizomes essential oil dose. The essential oil may stimulate the synthesis of estradiol by acting on the hypothalamic-pituitary-gonad axis. Furthermore, $E_{2}$ is the most physiologically active type of estrogen produced by granulosa cells of pre-ovulatory follicles through the aromatization of thecal androgen by the granulose cells of growing follicles [26], in response to LH and under the control of the hypothalamic-pituitary axis. Also, estradiol stimulates the proliferation of granulosa cells in follicles and serves to facilitate the actions of Follicle Stimulating Hormone (FSH) and Luteinizing Hormone (LH) [27]. Our finding shows significant and higher means values of LH and FSH in female Japanese quails which received the essential oil compared to the control. These results are in agreement with the findings of Saeid et al. [28] who reported that adding ginger at 50 and $100 \mathrm{mg} / \mathrm{kg}$ diet for 28,32 , 36,40 and 44 consecutive weeks in broilers significantly $(\mathrm{p}<0.05)$ increased LH and FSH serum level in these groups as compared with the control group.

With respect to the effect of ginger rhizomes essential oil on broiler biochemical parameters, the results presented in this study revealed that oral administration of essential oil at the selected levels increased the level of serum total proteins and globulin. These results are consistent with those of Zhang et al. [29] in broiler chickens treated with ginger rhizomes powder at doses of $5 \mathrm{~g} / \mathrm{kg}$ of diet. Conversely, other researchers recorded a significant decrease in serum proteins and globulins in broilers treated with ginger roots powder [20] [30]. The discrepancies in these results may be due to the difference in doses used, form of plant, route of administration as well as experimental conditions. The increase of total proteins and globulin may be due to phenol components of ginger rhizomes essential oil including gingerol shogaols, gingerdiol, gingerdione, and some related phenolic ketone derivatives [6], which possess potent antioxidant properties and consequently, elevate immune responses of Japanese quails.

In the present study, it was observed that: fertility, hatchability of fertile eggs and total hatchability rates increased with essential oil dose. These results are comparable to those found by Ali et al. [10] who reported that individually added of $1 \%$ thyme, $1 \%$ rosemary, $1 \%$ oregano and $0.5 \%$ to $1 \%$ curcuma to chicken diets increased fertility and hatchability. In fact, the ginger rhizome essential oil contains a number of compounds (alkaloids and terpenoid) possessing the antibacterial, antiviral, antifungal and/or anti-inflammatory activities. These properties enable the oil to attack any infections responsible for low female fertility rate. On the other hand, oxidative metabolism increased, especially in the final few days before hatching, as a normal result of embryonic growth. It is reported that over increment lipid peroxidation may lead to tissue damage [31], whereas diets with antioxidants properties as ginger may protect the embryo and therefore increase hatchability and chick's survival rate.

\section{Conclusion}

In conclusion, our findings show that ginger rhizomes essential oil through its 
diverse properties enhances bird reproductive performances, especially the reproductive organs weight, biochemical parameters, eggs weight and hatchability traits.

\section{References}

[1] Recoquillay, F. (2009) L'intérêt des huiles essentielles. [The Interest of Essential Oils.] $9^{\text {ème }}$ Journée Productions porcines et avicoles.

[2] Konstantopoulou, L.L., Vassilopoulou, L., Mavragani, T.P. and Scouras, Z.G. (1992) Insecticidal Effects of Essential Oils. A Study of the Effects of Essential Oils Extracted from Eleven Greek Aromatic Plants on Drosophila auraria. Experientia, 48, 616-619. https://doi.org/10.1007/BF01920251

[3] Afshin, Z., Fatemeh, F., Arash, K. and Behnam, A. (2012) Protective Effect of Ginger on Gentamicin-Induced Apoptosis in Testis of Rats. Advanced Pharmaceutical Bulletin, 2, 197-200.

[4] Bakkali, F., Averbeck, S., Averbeck, D. and Idaomar, M. (2008) Biological Effects of Essential Oils. Food and Chemical Toxicology, 46, 446-475.

https://doi.org/10.1016/j.fct.2007.09.106

[5] Wink, M. (2008) Evolutionary Advantage and Molecular Modes of Action of Multi-Component Mixtures in Phytomedicine. Current Drug Metabolism, 9, 996-1009. https://doi.org/10.2174/138920008786927794

[6] Zhao, X., Yang, Z.B., Yang, W.R., Wang, Y., Jiang, S.Z. and Zhang, G.G. (2011) Effects of Ginger Roots (Zingiber officinale) on Laying Performance and Antioxidant Status of Laying Hens and on Dietary Oxidation Stability. Poultry Science, 90, 1720-1727. https://doi.org/10.3382/ps.2010-01280

[7] Sekiwa, Y., Kubota, K., Kobayashi, A. (2000) Isolation of Novel Glucosides Related to Gingerdiol from Ginger and Their Antioxidative Activities. Journal of Agricultural and Food Chemistry, 48, 373-377. https://doi.org/10.1021/jf990674x

[8] Fuhrman, B., Rosenblat, M., Hayek, T., Coleman, R. and Aviram, M. (2000) Ginger Extract Consumption Reduces Plasma Cholesterol, Inhibits LDL Oxidation and Attenuates Development of Atherosclerosis in Atherosclerotic, Apolipoprotein E-Deficient Mice. Journal of Nutrition, 130, 1124-1131.

[9] Ahmad, N., Sulaiman, S., Mukti, N.A., Murad, N.A., Hamid, N.A.A. and Yusof, Y.A.M. (2006) Effects of Ginger Extract (Zingiber officinale Roscoe) on Antioxidant Status of Hepatocarcinoma Induced Rats. Malaysian Journal of Biochemistry and Molecular Biology, 14, 7-12.

[10] Ali, B.H., Blunden, G., Tanira, M.O. and Nemmar, A. (2008) Some Phytochemical, Pharmacological and Toxicological Properties of Ginger (Zingiber officinale Roscoe): A Review of Recent Research. Food and Chemical Toxicology, 46, 409-420. https://doi.org/10.1016/j.fct.2007.09.085

[11] Khan, R.U., Naz, S., Nikousefat, Z., Tufarelli, V., Javdani, M., Qureshi, M.S. and Laudadio, V. (2012) Potential Applications of Ginger (Zingiber officinale) in Poultry Diets. World s Poultry Science Journal, 68, 245-252.

https://doi.org/10.1017/S004393391200030X

[12] Abdollah, A., Abolghasem, G., Ardashir, S.A. and Hossein, M. (2014) Effects of Ginger Root (Zingiber officinale) on Egg Yolk Cholesterol, Antioxidant Status and Performance of Laying Hens. Journal of Applied Animal Research, 39, 19-21.

[13] Malekizadeh, M., Moeini, M.M. and Ghazi, S.H. (2012) The Effects of Different Levels of Ginger (Zingiber officinale Roscoe) and Turmeric (Curcuma longa Linn) Rhi- 
zomes Powder on Some Blood Metabolites and Production Performance Characteristics of Laying Hens. Journal of Agricultural Science and Technology, 14, 127-134.

[14] Turgeon, M. (2016) Profil des produits forestiers-première transformation. [Forest Products Profile-First Transformation.] Huiles essentielles, $16 \mathrm{p}$.

[15] Wang, L. and Weller, L.C. (2006) Recent Advances in Extraction of Nutraceuticals from Plants. Trends in Food Science and Technology, 17, 300-312.

[16] Jourdain, R. (1980) L'aviculture en milieu tropical. (E dt) Jourdain. [Poultry Farming in a Tropical Environment.] International Couloumiers, 43-45.

[17] Gornal, A.G., Bardwil, G.S. and David, M.M. (1949) Determination of Serum Proteins by Mean of Biuret Reactions. Biological Chemistry, 177, 751-766.

[18] Abdel-Fattah, S.A., El-Sanhoury, M.H., El-Mednay, N.M. and Abdel-Azeem, F. (2008) Thyroid Activity, Some Blood Constituents, Organs Morphology and Performance of Broiler Chicks Fed Supplemental Organic Acids. International Journal of Poultry Science, 7, 215-222. https://doi.org/10.3923/ijps.2008.215.222

[19] Bulbul, T., Yesilba, G.D., Ulutas, E., Biricik, H., Gezen, S.S. and Bulbul, A. (2014) Effect of Myrtle (Myrtus communis L.) Oil on Performance, Egg Quality, Some Biochemical Values and Hatchability in Laying Quails. Revue de Médecine Vétérinaire, 165, 280-288.

[20] Nahed, S., Tamer, A., Amera, A.E.-L. and Emad, G. (2014) The Effects of Dietary Supplementation of Different Levels of Thyme (Thymus vulgaris) and Ginger (Zingiber officinale) Essential Oils on Performance, Hematological, Biochemical and Immunological Parameters of Broiler Chickens. Global Veterinaria, 12, 736-744.

[21] Arpášová, H., Gálik, B., Hrncár, C., Fik, M., Herkel, R. and Pistová, V. (2015) The Effect of Essential Oils on Performance of Laying Hens. Animal Science and Biotechnologies, 48, 8-14.

[22] Othman, R.A., Amin, M.R. and Rahman, S. (2014) Effect of Egg Size, Age of Hen and Storage Period on Fertility, Hatchability, Embryo Mortality and Chick Malformations in Eggs of Japanese Quail (Coturnix coturnix japonica). Journal of Agriculture and Veterinary Science, 7, 101-106. https://doi.org/10.9790/2380-0714101106

[23] Seker, I., Kul, S. and Bayraktar, M. (2005) Effects of Storage Period and Egg Weight of Japanese Quails Eggs on Hatching Results. Archiv Tierzucht, Dummerstorf, 48, 518-526.

[24] Wallace, R.A. (1985) Vitellogenesis and Oocyte Growth in Nonmammalian Vertebrates. In: Developmental Biology, 127-177.

[25] Yu, J.Y.-L., Campbell, L.D. and Marquardt, R.R. (1971) Sex Hormone Control Mechanisms. I. Effect of Estrogen and Progesterone on Major Cellular Components in Chicken (Gallus domesticus) Oviducts. Canadian Journal of Biochemistry and Cell Biology, 49, 348-356.

[26] Hüseyin, B.Ç. (2013) Estrogen and Growth Hormone and Their Roles in Reproductive Function. International Journal of Animal and Veterinary Advances, 5, 21-28.

[27] Richards, J.S. (1980) Maturation of Ovarian Follicles: Actions and Interactions of Pituitary and Ovarian Hormones on Follicular Cell Differentiation. Physiological Reviews, 60, 51-89.

[28] Saeid, J.M., Shanoon, A.K. and Marbut, M.M. (2011) Effects of Zingiber officinale Aqueous Extract on Semen Characteristic and Some Blood Plasma Parameters in the Broilers Breeder Male. International Journal of Poultry Science, 10, 629-633. https://doi.org/10.3923/ijps.2011.629.633

[29] Zhang, G.F., Yang, Z.B., Wang, Y., Yang, W.R., Jiang, S.Z. and Gai, G.S. (2009) Ef- 
fects of Ginger Root (Zingiber officinale) Processed to Different Particle Sizes on Growth Performance, Antioxidant Status and Serum Metabolites of Broiler Chickens. Poultry Science, 88, 2159-2166. https://doi.org/10.3382/ps.2009-00165

[30] AL-Homidan, A.A. (2005) Efficacy of Using Different Sources and Levels of Allium sativum and Zingiber officinale on Broiler Chicks Performance. Saudi Journal of Biological Sciences, 12, 96-102.

[31] Surai, P.F. (1999) Tissue-Specific Changes in the Activities of Antioxidant Enzymes during the Development of the Chicken Embryo. British Poultry Science, 40, 397-405. https://doi.org/10.1080/00071669987511 